\title{
HMGB1 in the Pathogenesis of Nasal Inflammatory Diseases and its Inhibition as New Therapeutic Approach: A Review from the Literature
}

\author{
Luisa Maria Bellussi ${ }^{1}$ Serena Cocca ${ }^{1}$ Giulio Cesare Passali ${ }^{2}$ Desideri Passali ${ }^{1}$ \\ 1 ENT Department, University of Siena, Siena, Italy \\ 2 ENT Department, Sacred Heart University, Rome, Italy \\ Address for correspondence Luisa Maria Bellussi, MD, PhD, ENT \\ Department, University of Siena, Siena, Italy \\ Int Arch Otorhinolaryngol 2017;21:390-398. \\ (e-mail: I.bellussi@virgilio.it).
}

\begin{abstract}
Introduction This study is a systematic review on recent developments about the importance of HMGB1 protein in the pathogenesis of rhino-sinusal inflammatory diseases. We also report data on the use of 18 - $\beta$-glycyrrhetic acid (GA), which has been shown able to inhibit the pro-inflammatory activities of HMGB1, in young patients affected by allergic rhinitis and complaining of nasal obstruction as main symptom. Objectives The objective of this study was to review the literature to demonstrate the importance of HMGB1 in the pathogenesis of nasal inflammatory disorders and understand whether the inhibition of this protein may be an efficacious and innovative therapeutic strategy for patients with rhino-sinusal inflammation.

Data Synthesis Authors searched for pertinent articles indexed in PubMed, Scopus, and other health journals between 2004 and 2015.

In total, the authors gathered 258 articles: 219 articles through Pubmed and 39 articles from other search engines. The search terms used were as follows: HMGB1 AND

Keywords

- rhino-sinusal inflammation

- HMGB1

- allergic rhinitis

- chronic rhinosinusitis

- glycyrrhetic acid "respiratory epithelium," "airway inflammation," "rhinitis," "allergic rhinitis," "rhinosinusitis," "nasal polyposis," "glycyrrhetic acid," "children."

Conclusions Patients with severe symptoms have the highest serum levels and the highest extracellular expression of HMGB1. GA inhibits HMGB1 chemotactic and mitogenic function by a scavenger mechanism on extracellular HMGB1 accumulation stimulated by lipopolysaccharides in vitro. Treatment of allergic rhinitis with GA is not associated with local or systemic side effects in children and adults.
\end{abstract}

\section{Introduction}

Chronic inflammatory diseases of the respiratory epithelium (such as allergic rhinitis, chronic rhinosinusitis with/out nasal polyposis, asthma, chronic obstructive pulmonary disease, cystic fibrosis) are increasingly prevalent and are a financial burden for society. Allergic rhinitis (AR), the allergen-mediated inflammation of the nasal mucosa, is one of the most common illnesses in childhood and adolescence, affecting $10-40 \%$ of young people worldwide. ${ }^{1,2}$ Its prevalence among children has been significantly increasing over the last two

received

June 28, 2016

accepted

October 31, 2016

published online

January 4, 2017 decades, accompanied by a parallel increase in comorbidities such as asthma, rhinosinusitis, otitis media. ${ }^{3}$

Major symptoms of AR typically include nasal obstruction and rhinorrhea accompanied by sneezing, itchy nose, eyes, and throat. Nasal congestion is a hallmark of AR and is often the symptom patients find most troublesome and would like most to prevent. ${ }^{4,5}$ Furthermore, sleep apnea and snoring, such as sleep-disordered breathing, are associated with nasal obstruction. ${ }^{6-8}$ All these symptoms negatively affect not only quality of sleep but also daily life, school performance, social activities, physical and emotional health.

Copyright $\odot 2017$ by Thieme Revinter

Publicações Ltda, Rio de Janeiro, Brazil

License terms

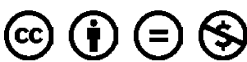


Allergic rhinitis is characterized by an inflammatory reaction. Pro-inflammatory mediators play an important role in developing the persistence of nasal inflammation. ${ }^{9}$

High Mobility Group Box 1 (HMGB1), a pro-inflammatory cytokine, has been recently shown to play a role in the pathogenesis of several inflammatory diseases like hepatitis, arthritis, stroke, liver and kidney ischemia, sepsis, ${ }^{10}$ rheumatoid arthritis, ${ }^{11}$ systemic lupus erithematosus. ${ }^{12}$

Under normal conditions, this protein is located in the cell nucleus where it carries out specific structural and/or metabolic tasks; when released extracellularly, it becomes an activator of the innate immunity and powerful inflammatory factor. ${ }^{10}$

The innate immune system relies on cellular elements (monocytes/macrophages, APCs, NK-cells) and various pattern-recognition receptors (PRRs) such as TLRs, which should be considered as the first line of defense against invading pathogens as well as aeroallergens. The interaction between microbial antigens (Pathogen-Associated-Molecular-Patterns PAMPs), allergens, or even endogenous peptides released from damaged and necrotic cells, triggers the release of inflammatory cytokines for host defense. ${ }^{13}$ HMGB1 binds to TLR4, TLR9, and RAGE and through activation of the transcriptional factor Nuclear Factor kB (NF-kB) causes the release of pro-inflammatory mediators, cytokines, and chemokines. It induces endothelial activation and increases survival of inflammatory cells, mainly eosinophils. ${ }^{14}$ Low levels of HMGB1 usually mediate beneficial responses in reaction to environmental or endogenous dangers, enhancing both the innate and adaptive immune system. High levels of HMGB1 cause acute damage: its binding to RAGE receptors, expressed by endothelial cells, promotes eosinophils-recruitment, their survival, and release of ECP and MBP with subsequent epithelial barrier damage.

In recent years, our research addressed the HMGBís role in the pathogenesis of chronic nasal mucosa inflammatory diseases such as allergic rhinitis, chronic rhinosinusitis, and nasal polyposis.

The aim of this review is to show the importance of HMGB1 in the pathogenesis of nasal inflammatory disorders to understand if the inhibition of this protein may be an efficacious and innovative therapeutic strategy for patients with rhino-sinusal inflammation.

\section{Search Methods}

We performed a literature search of pertinent articles indexed in PubMed, Scopus, and other health journals between 2004 and 2015. They identified additional articles by reviewing the bibliography of retrieved articles. The search was expanded to other search engines including Springerlink, Sage Journal Online, ScienceDirect, and Wiley Online Library.

The search terms used were as follows: HMGB1 AND "respiratory epithelium," "airway inflammation," "rhinitis," "allergic rhinitis," "rhinosinusitis," "nasal polyposis," "glycyrrhetic acid," "children."

Two researchers selected and screened the articles. They resolved disagreement through discussion. The inclusion criteria were full text articles published in English between
January 2004 and October 2015. They read the full texts of the studies deemed relevant by title and abstract and independently evaluated them based on eligibility criteria. An additional hand search was performed in the reference lists of all full texts of all studies identified during the initial search. This review article adopted the Preferred Reporting Items for Systematic Reviews and Meta-Analyses (PRISMA) guidelines. - Fig. 1 summarizes the literature search strategy according to the PRISMA guidelines.

\section{Review of Literature}

In total, 258 articles were gathered; 219 articles through Pubmed and 39 articles from other search engines. Out of 258 articles, 77 of them were duplicates, 139 articles were not related to the topic searched, 15 articles were only available in Chinese language, and 6 articles were not accessible. Accordingly, we excluded 237 articles. In total, 21 articles related to HMGB1 expression in upper airways inflammation and the effects of its blockage by inhibitors in clinical trials have been selected for our review. ${ }^{15-35}$ The search results are summarized in - Table 1.

\section{HMGB1, Rhinitis, and Rhinosinusitis}

The aims of our first studies ${ }^{5-16}$ were 1 ) to determine whether HMGB1 increases in chronic rhinosinusitis with nasal polyps (CRSwNP); 2) to determine whether its expression is associated with eosinophils, TNF- $\alpha$, IL5, and IL8 cytokines typically present in chronic inflammation of the nose and paranasal sinuses; 3 ) to investigate the hypothesis that this protein plays a role in the pathogenesis of nasal polyposis. For this purpose, ${ }^{16}$ we collected nasal polyps tissue from 21 patients with CRSwNP, including one patient with asthma and two patients with AR, as well as from 8 healthy control subjects. CRSwNP was confirmed by medical history, nasal endoscopy, and computed tomography. Control subjects were patients with rhinorrhoea of cerebrospinal fluid, fracture of the optic canal or a benign skull base tumor, and without history of sinus disease or asthma. We collected biopsy specimens of nasal mucosa and nasal polyps before surgery. Samples were stained with haematoxylin-eosin (HE) and immunohistochemistry (IHC) to investigate HMGB1 protein expression and its correlation with eosinophils and IL-5, IL-8, and TNF- $\alpha$ cytokines. According to HE staining, we divided subjects into three groups: 8 control subjects, 10 eosinophilic CRSwNP patients, and 11 non-eosinophilic CRSwNP patients.

Expression of HMGB1 in inflammatory cells in patients with both eosinophilic and non-eosinophilic CRSwNP was significantly increased compared with the controls. The HMGB1 protein was increased in the nucleus of epithelial cells or as focal subepithelial infiltration and in inflammatory cells of patients; in contrast, HMGB1 staining was significantly lower in epithelial cytoplasm. No significant difference in HMGB1 expression between Eos CRSwNP (Eosinophilic Chronic Rhinosinusitis with Nasal Polyposis) and non-Eos CRSwNP, was found suggesting that HMGB1 may play a crucial role in the pathogenesis of chronic 


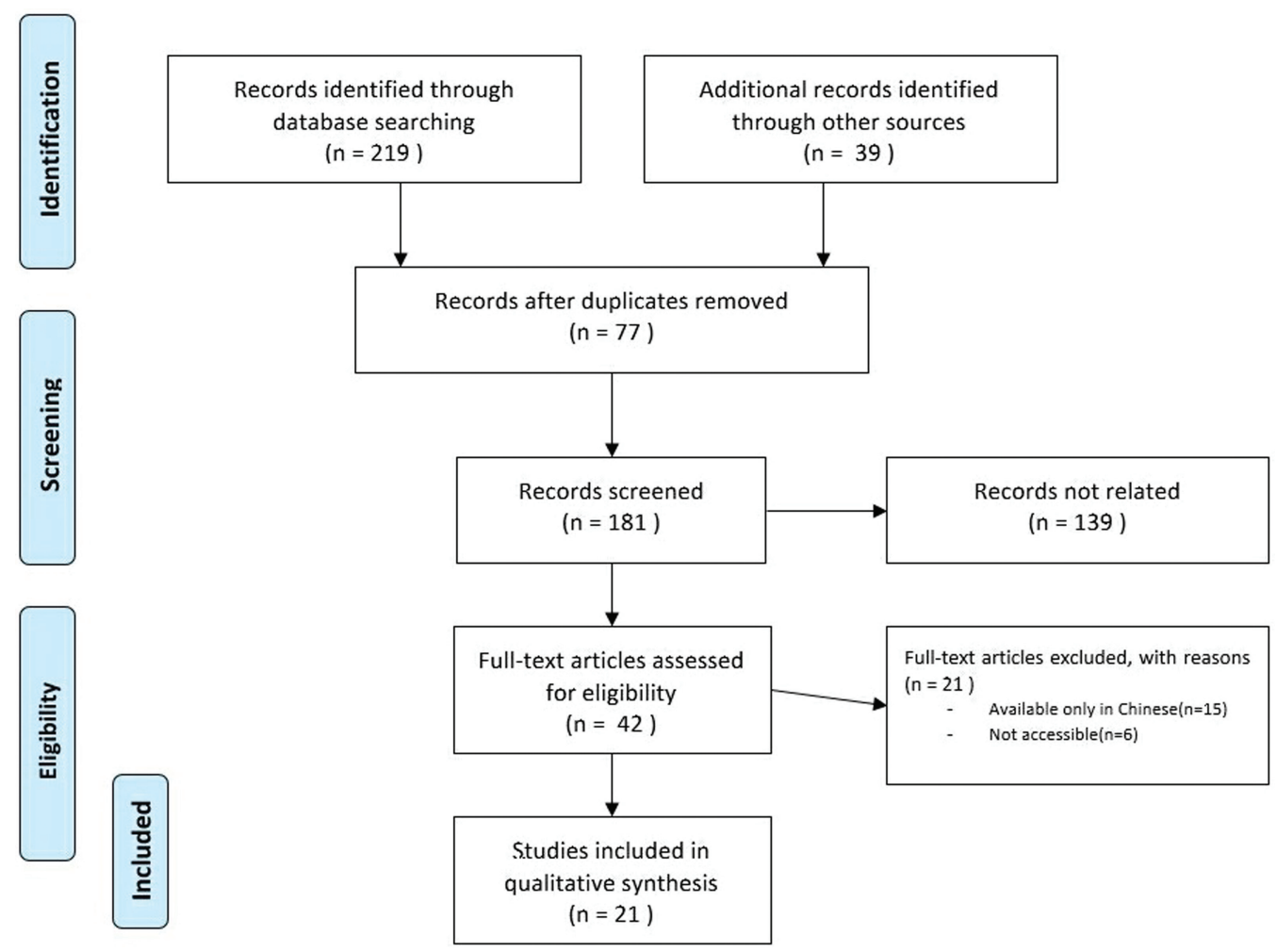

Fig. 1 Flow chart of steps in systematic review.

rhinosinusitis with nasal polyps irrespective of the etiologic stimuli.

The study by Hong et $\mathrm{al}^{25}$ has confirmed by IHC, semi quantitative reverse transcriptase-polymerase chain reaction (RT-PCR), real-time PCR, and Western blot analysis that HMGB1 is more highly expressed in epithelial cells and in inflammatory cells of patients with CRS.

More recently, another study by our research group has confirmed the hypothesis that up-regulation of HMGB1 could be a significant marker of eosinophilic CRSwNP and contributes to the pathogenesis of CRSwNP along IL-5, IL-8, and TNF- $\alpha{ }^{29}$

The study by Bellussi et al $^{26}$ was aimed at confirming the role of HMGB1 in nasal polyposis and CRS as well as investigating whether its expression and localization (nuclear, cytoplasmic, extracellular) is in some way related to the severity and complexity of the histological and clinical manifestations. With this aim, we randomly selected 10 biopsies of nasal mucosa from patients with CRS without NP and 31 CRS with NP; as controls, we included 3 biopsies of normal nasal mucosa harvested from healthy patients with no symptoms of chronic rhinosinusitis or nasal allergies: the pathologist found no inflammatory infiltrate, fibrosis, newly formed vessels, or eosinophils in these specimens.

Patient assessment was based on clinical history, symptoms collection, and severity evaluation, presence or absence of allergy, asthma, acetylsalicylic acid intolerance, other allergic manifestations (drug allergy), previous surgery, and recurrences.

The tissue samples were tested by IHC using HMGB1 polyclonal antibody and thereafter counterstained with Meyer's hematoxylin. We analyzed the biopsy samples with two different goals: 1) to evaluate the HMGB1 expression and its cellular distribution: for this purpose we estimated nuclear, cytoplasmic, and extracellular staining as a percentage in the area in question and classified the intensity of HMGB1 positivity as a percentage; and 2) to compare this distribution with the inflammatory infiltrate and severity of clinical manifestations.

As expected, all the patients with a higher inflammatory infiltrate and eosinophils presence had an allergic-hyperreactive condition or comorbidity, which may induce and sustain the nasal mucosa inflammation. Since, according to our hypothesis, HMGB1 could be a marker of certain disease activity, we evaluated allergic patients and non-allergic patients for the protein. We found a statistical significance for extracellular HMGB1 $(p=0.0380)$ and nuclear HMGB1 $(p=0.0499)$, both increased in allergic patients. Additionally, we assessed the presence of other allergic-hyperactive conditions such as asthma, NSAIDs (Non-Steroidal Anti-Inflammatory Drugs) intolerance, antibiotic allergy on HMGB1 levels. We interpreted the results obtained as a statistical significance between extracellular HMGB1 and NSADs intolerance $(p=0.0022)$. The higher extracellular HMGB1 expression in patients with more severe clinical and inflammatory manifestations and the presence of associated co-morbidities confirms the role of HMGB1 in the induction of the inflammatory reaction and evidences its importance for the process becoming chronic.

In this regard, other authors found that the HMGB1 level in nasal lavage fluid from patients affected by CRS correlates with severity of inflammation. ${ }^{32}$ They determined levels of HMGB1 and pro-inflammatory cytokines (TNF $\alpha$, IL-1b, IL-8) 
Table 1 Summary of reviewed articles related to HMGB1 expression in upper airways inflammation and the effects of its blockage by inhibitors

\begin{tabular}{|c|c|c|c|c|}
\hline $\begin{array}{l}\text { Author } \\
\text { (year) }\end{array}$ & Title & Number of cases & HMGB1* & Glycyr. acid** \\
\hline $\begin{array}{l}\text { Mansi et } \mathrm{al}^{21} \\
(2012)\end{array}$ & $\begin{array}{l}\text { A before-after assessment of the } \\
\text { efficacy of Narivent in the treatment } \\
\text { of symptoms associated with allergic } \\
\text { rhinitis in a pediatric population. }\end{array}$ & $\begin{array}{l}20 \text { patients of both genders, aged } \\
5-18 \text { years old, with persistent or } \\
\text { intermittent allergic rhinitis. }\end{array}$ & レ & レ \\
\hline $\begin{array}{l}\text { Damiani et al }{ }^{18} \\
(2012)\end{array}$ & $\begin{array}{l}\text { Short-term efficacy of Narivent in the } \\
\text { treatment of nasal congestion. }\end{array}$ & $\begin{array}{l}36 \text { patients ( } 15 \text { women and } 21 \text { men) } \\
\text { with nasal congestion. Median age } \\
42 \text { years. }\end{array}$ & レ & レ \\
\hline $\begin{array}{l}\text { Damiani et } \text { al }^{19} \\
(2012)\end{array}$ & $\begin{array}{l}\text { Long-term efficacy of Narivent in the } \\
\text { treatment of nasal congestion. }\end{array}$ & $\begin{array}{l}56 \text { patients ( } 28 \text { women and } 28 \text { men) } \\
\text { with persistent nasal congestion. } \\
\text { Median age } 48.5 \text { years. }\end{array}$ & レ & レ \\
\hline $\begin{array}{l}\text { Damiani et } \mathrm{al}^{20} \\
(2012)\end{array}$ & $\begin{array}{l}\text { Economic impact of treatments for } \\
\text { controlling symptoms associated with } \\
\text { rhinitis: an evaluation of Narivent vs } \\
\text { standard therapy. }\end{array}$ & $\begin{array}{l}\text { Literature review: } 6680 \text { papers in the } \\
\text { past } 5 \text { years. Data extraction \& prob- } \\
\text { ability density reconstruction. Monte } \\
\text { Carlo sampling. }\end{array}$ & レ & レ \\
\hline $\begin{array}{l}\text { Damiani et } \mathrm{al}^{22} \\
(2012)\end{array}$ & $\begin{array}{l}\text { A single-center, before-after study of } \\
\text { the short- and long-term efficacy of } \\
\text { Narivent in the treatment of nasal } \\
\text { congestion. }\end{array}$ & $\begin{array}{l}92 \text { patients with persistent nasal } \\
\text { congestion divided in two groups: } \\
\text { Group } 1 \text { consisting of } 36 \text { patients } \\
\text { (7-day treatment) and Group } 2 \\
\text { consisting of } 56 \text { patients ( } 30 \text {-day } \\
\text { treatment). }\end{array}$ & レ & レ \\
\hline $\begin{array}{l}\text { Cuppari et } \mathrm{al}^{23} \\
(2012)\end{array}$ & $\begin{array}{l}\text { HMGB1 and allergic rhinitis in chil- } \\
\text { dren: preliminary results after corti- } \\
\text { costeroids or glycyrrhetic acid } \\
\text { intranasal treatment. }\end{array}$ & $\begin{array}{l}59 \text { patients evaluated. } 35 \text { children } \\
\text { ( } 19 \text { boys and } 16 \text { girls, median age } \\
9.3 \pm 3.7 \text { years) with allergic rhinitis } \\
\text { and monosensitized to Parietaria, } \\
\text { were evaluated. The control group } \\
\text { consisted of } 24 \text { healthy children } \\
\text { ( } 11 \text { boys and } 13 \text { girls, median age } \\
9.1 \pm 4.1 \text { years). }\end{array}$ & $\boldsymbol{V}$ & レ \\
\hline $\begin{array}{l}\text { Passali et al }{ }^{15} \\
(2012)\end{array}$ & $\begin{array}{l}\text { High mobility group box } 1 \text { (HMGB1): a } \\
\text { new protein in the pathogenesis of } \\
\text { ENT inflammatory and infectious } \\
\text { disease. }\end{array}$ & $\begin{array}{l}\text { Preliminary data about the role of } \\
\text { HMGB1 protein in ENT inflammatory } \\
\text { and infectious. }\end{array}$ & レ & - \\
\hline $\begin{array}{l}\text { Bellussi et al }{ }^{16} \\
(2012)\end{array}$ & $\begin{array}{l}\text { The role of high mobility group box } 1 \\
\text { chromosomal protein in the patho- } \\
\text { genesis of chronic sinusitis and nasal } \\
\text { Polyps. }\end{array}$ & $\begin{array}{l}\text { Nasal polyps tissue from } 21 \text { patients } \\
\text { with CRSwNP including } 1 \text { patient with } \\
\text { asthma and } 2 \text { patients with allergic } \\
\text { rhinitis and } 8 \text { healthy control subjects } \\
\text { were collected. }\end{array}$ & レ & - \\
\hline $\begin{array}{l}\text { Salpietro et al }{ }^{17} \\
(2013)\end{array}$ & $\begin{array}{l}\text { Nasal High-Mobility Group Box-1 } \\
\text { Protein in Children with Allergic } \\
\text { Rhinitis. }\end{array}$ & $\begin{array}{l}104 \text { allergic rhinitis subjects } \\
\text { ( } 48 \text { males and } 56 \text { females, median } \\
\text { age } 10.3 \pm 3.4 \text { years) and } 97 \text { healthy } \\
\text { children ( } 42 \text { males and } 55 \text { females, } \\
\text { median age } 9.8 \pm 4.1 \text { years). }\end{array}$ & レ & - \\
\hline $\begin{array}{l}\text { Hong et } \mathrm{al}^{25} \\
(2013)\end{array}$ & $\begin{array}{l}\text { Increased expression of high-mobility } \\
\text { group protein B1 in chronic } \\
\text { rhinosinusitis. }\end{array}$ & $\begin{array}{l}\text { Paranasal sinus mucosa was obtained } \\
\text { from } 10 \text { patients with CRS and } 10 \\
\text { patients without CRS. }\end{array}$ & レ & - \\
\hline $\begin{array}{l}\text { Bellussi et } \mathrm{al}^{26} \\
(2013)\end{array}$ & $\begin{array}{l}\text { Are HMGB1 protein expression and } \\
\text { secretion markers of upper airways } \\
\text { inflammatory diseases? }\end{array}$ & $\begin{array}{l}10 \text { biopsies of nasal mucosa from } \\
\text { patients with CRS without NP and } 31 \\
\text { CRS with NP were randomly selected. } \\
\text { As controls were included } 3 \text { biopsies } \\
\text { of normal nasal mucosa that were } \\
\text { harvested from healthy patients with } \\
\text { no symptoms or nasal allergies. } \\
\text { (Mean age }=47.35 \text { years) }\end{array}$ & レ & - \\
\hline $\begin{array}{l}\text { Chen et }\left.a\right|^{27} \\
(2013)\end{array}$ & $\begin{array}{l}\text { LPS may enhance expression and re- } \\
\text { lease of HMGB1 in human nasal epi- } \\
\text { thelial cells in vitro. }\end{array}$ & $\begin{array}{l}\text { Nasal polyps and paranasal sinus } \\
\text { mucosa from } 10 \text { patients requiring } \\
\text { surgery for their sinusitis }\end{array}$ & レ & - \\
\hline
\end{tabular}


Table 1 (Continued)

\begin{tabular}{|c|c|c|c|c|}
\hline $\begin{array}{l}\text { Author } \\
\text { (year) }\end{array}$ & Title & Number of cases & HMGB1* & Glycyr. acid** \\
\hline $\begin{array}{l}\text { Ullah et al }{ }^{28} \\
(2014)\end{array}$ & $\begin{array}{l}\text { Receptor for advanced glycation end } \\
\text { products and its ligand high-mobility } \\
\text { group box } 1 \text { mediate allergic airway } \\
\text { sensitization and airway } \\
\text { inflammation. }\end{array}$ & $\begin{array}{l}\text { TLR4 }(-\mid-) \text {, RAGE }(-\mid-) \text {, and } \\
\text { RAGE-TLR4 }(-\mid- \text { ) mice received } \\
\text { intranasal exposure to Dermatopha- } \\
\text { goides pteronyssinus or Blatella } \\
\text { germanica extracts, and researchers } \\
\text { measured features of allergic inflam- } \\
\text { mation during the sensitization or } \\
\text { challenge phase. They used anti- } \\
\text { HMGB1 antibody and the IL-1 receptor } \\
\text { antagonist Anakinra to inhibit HMGB1 } \\
\text { and the IL-1 receptor, respectively. }\end{array}$ & $レ$ & - \\
\hline $\begin{array}{l}\text { Mansi et al } \\
(2014)\end{array}$ & $\begin{array}{l}\text { Allergic Rhinitis in Children: A Ran- } \\
\text { domized Clinical Trial Targeted at } \\
\text { Symptoms. }\end{array}$ & $\begin{array}{l}40 \text { patients, aged between } 5 \text { and } \\
18 \text { years old, were randomly divided } \\
\text { into two groups ( } 20 \text { cases and } 20 \\
\text { controls) and followed for } 30 \text { days. }\end{array}$ & レ & レ \\
\hline $\begin{array}{l}\text { Chen et al }{ }^{29} \\
(2014)\end{array}$ & $\begin{array}{l}\text { Increase of high mobility group box } \\
\text { chromosomal protein } 1 \text { in eosino- } \\
\text { philic chronic rhinosinusitis with nasal } \\
\text { polyps. }\end{array}$ & $\begin{array}{l}\text { Researchers collected nasal polyps } \\
\text { specimens from } 41 \text { patients with } \\
\text { CRSwNP ( } 20 \text { eosinophilic and } 21 \\
\text { noneosinophilic) undergoing func- } \\
\text { tional endoscopic sinus surgery } \\
\text { (FESS). Biopsies of uncinate process, } \\
\text { and ethmoidal mucosa from } 9 \text { non- } \\
\text { CRS patients were used as controls. }\end{array}$ & レ & - \\
\hline $\begin{array}{l}\text { Paris et al } \\
(2014)\end{array}$ & $\begin{array}{l}\text { Damage-associated molecular } \\
\text { patterns stimulate interleukin } 33 \\
\text { expression in nasal polyp epithelial } \\
\text { cells. }\end{array}$ & $\begin{array}{l}\text { Ethmoid tissue was obtained from } \\
8 \text { recalcitrant CRSwNP and } 9 \text { control } \\
\text { subjects during endoscopic sinus } \\
\text { surgery (ESS). }\end{array}$ & レ & - \\
\hline $\begin{array}{l}\text { Musumeci et } \mathrm{al}^{31} \\
(2014)\end{array}$ & $\begin{array}{l}\text { An overview on HMGB1 inhibitors as } \\
\text { potential therapeutic agents in } \\
\text { HMGB1-related pathologies. }\end{array}$ & $\begin{array}{l}\text { Review describes various approaches } \\
\text { recently proposed in the literature to } \\
\text { inhibit HMGB1 and the related } \\
\text { inflammatory processes, especially } \\
\text { focusing on the block of } \\
\text { RAGE-HMGB1 signaling. }\end{array}$ & レ & レ \\
\hline $\begin{array}{l}\text { Min et } a^{32} \\
(2015)\end{array}$ & $\begin{array}{l}\text { Level of secreted HMGB1 correlates } \\
\text { with severity of inflammation in } \\
\text { chronic rhinosinusitis. }\end{array}$ & $\begin{array}{l}\text { Total } 63 \text { nasal lavage fluid samples } \\
\text { were collected from } 38 \text { patients } \\
\text { (16-76 years old) with chronic rhino- } \\
\text { sinusitis who underwent endoscopic } \\
\text { sinus surgery. }\end{array}$ & $\nu$ & - \\
\hline $\begin{array}{l}\text { Cavone et } \mathrm{al}^{33} \\
(2015)\end{array}$ & $\begin{array}{l}\text { Increase in the Level of Proinflamma- } \\
\text { tory Cytokine HMGB1 in Nasal Fluids } \\
\text { of Patients with Rhinitis and its Se- } \\
\text { questration by Glycyrrhizin Induces } \\
\text { Eosinophil Cell Death. }\end{array}$ & $\begin{array}{l}170 \text { Allergic Rhinitis subjects ( } 87 \text { males } \\
\text { and } 83 \text { females; median age, } 10.3 \pm 3.4 \\
\text { years). } 1 \text { puff of saline ( } 29 \text { males and } 28 \\
\text { females), one group received } 1 \text { puff of } \\
\text { Budesonide ( } 32 \text { males and } 25 \text { females) } \\
\text { and one group received } 1 \text { puff of Nar- } \\
\text { ivent (DMG, Rome, Italy) ( } 30 \text { males and } \\
26 \text { females) into each nostril } 2 \text { times a } \\
\text { day for } 1 \text { week. }\end{array}$ & レ & レ \\
\hline $\begin{array}{l}\text { Dzaman et } \mathrm{al}^{34} \\
(2015)\end{array}$ & $\begin{array}{l}\text { Expression of the receptor for ad- } \\
\text { vanced glycation end products, a } \\
\text { target for high mobility group box } 1 \\
\text { protein, and its role in recalcitrant } \\
\text { rhinosinusitis with nasal polyps. }\end{array}$ & $\begin{array}{l}25 \text { patients with recalcitrant CRSwNPs } \\
\text { are included in the study ( } 13 \text { males } \\
\text { and } 12 \text { females. Median age: } 47 \text { years; } \\
\text { range } 24-77 \text { years). }\end{array}$ & レ & - \\
\hline $\begin{array}{l}\text { Dzaman et } \mathrm{al}^{35} \\
(2015)\end{array}$ & $\begin{array}{l}\text { High motility group box } 1 \text { (HMGB1) } \\
\text { protein and its receptor for advanced } \\
\text { glycation end products (RAGE) } \\
\text { expression in chronic rhinosinusitis } \\
\text { without nasal polyps. }\end{array}$ & $\begin{array}{l}37 \text { patients with CRS without nasal } \\
\text { polyps ( } 19 \text { males and } 18 \text { females; } \\
\text { median age } 42 \text { years, range } 15-71 \\
\text { years) and } 26 \text { normal controls ( } 18 \\
\text { males and } 8 \text { females. Median age } \\
40 \text { years; range } 16-69 \text { years) were } \\
\text { enrolled in this study. }\end{array}$ & 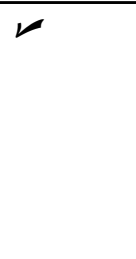 & - \\
\hline
\end{tabular}

Abbreviation: Glycyr., glycyrrhetic. Notes:*dosage of HMGB1 in upper airways inflammation; **therapeutic effect evaluation of glycyrrhetic acid. 
by enzyme-linked immunoassay and resulted positively correlated with the Lund-Mackay score. The results of this study show that HMGB1 can be considered an inflammatory mediator associated with the severity of chronic rhinosinusitis.

The paper by Chen et $\mathrm{al}^{27}$ demonstrated that HNE cells are a source of HMGB1 and that LPS triggers active release of HMGB1 and a "recycle" of injurious proinflammatory mediators.

In sum, our findings corroborate those of the literature in suggesting that HMGB1 plays an important role in the induction and prolongation of the mechanisms of infection or injury-elicited inflammatory response of HNE cells.

\section{Children and Allergic Rhinitis}

Salpietro ${ }^{17}$ has demonstrated that children with AR have higher HMGB1 concentration than non-allergic subjects in sputum, plasma, and nasal lavage fluid. They conducted the study on 200 children (104 AR subjects and 97 healthy children). AR subjects presented nasal obstruction, nasal itching, sneezing, watery rhinorrhea, and positive results for the Parietaria pollen SPT. We collected blood sampling and nasal lavage in all children. Total IgE serum levels and peripheral eosinophils count were significantly higher in allergic children in comparison with healthy children $(p \leq$ 0.01 for both). HMGB1 levels in nasal lavage fluid were higher in children with AR than in controls and the highest levels of HMGB1 were found in the group of children with severe symptoms (HMGB1 related to visual analogue scale values). There was no relationship between HMGB1 levels and serum total IgE levels or eosinophils count.

As stated in ARIA (Allergic Rhinitis and its Impacts on Asthma) guidelines, pharmacological treatment must be individualized and poly-pharmacy must be avoided. The treatment should take into account efficacy, safety, costeffectiveness of medications, patient's preference, likely adherence to recommendations, severity and control of the disease, and the presence of comorbidities. ${ }^{36}$

Nasal decongestants effectively reduce nasal obstruction. Despite their widespread use, local and systemic side effects are frequent and it is advisable to limit their period of use by adults and otherwise healthy patients. ${ }^{37}$

Nowadays, the main pharmacological therapies for AR are: antihistamines and corticosteroids (CS).

Antihistamines are particularly indicated in children because they tend to prefer oral medications to intranasal ones. First generation antihistamines are not usually recommended due to their sedative effect and the consequent impairment of psychomotor, cognitive, and academic functions in children, fatigue, paradoxical hyperactivity, insomnia, and irritability. ${ }^{38}$ Second generation antihistamines have allowed overcoming these adverse effects.

The use of intranasal H1-antihistamines, like levocabastine and azelastine, has the benefits of rapid onset of action and a few adverse effects. However, although there is a beneficial effect over symptoms in the organ to which they are administered, they usually have little effect elsewhere. These drugs are useful in children with symptoms limited to the nose or the eyes.

Montelukast is not approved in every country, and is recommended only in patients over 6 years of age. ${ }^{39}$
Cromones have been one of the common drugs used for allergic rhinoconjunctivitis in children, but they are less effective than intranasal steroids or $\mathrm{H} 1$ antihistamines. It is important to note that in children, these drugs are free from side effects. However, a dosage of 4-6 times a day is required for cromoglycate and compliance with treatment is often difficult. ${ }^{38}$

Oral glucocorticosteroids and depot-preparations should be avoided in the treatment of rhinitis in young children, whereas intranasal glucocorticosteroids are the most effective therapy for allergic rhinoconjunctivitis. Topical nasal corticosteroids are commonly prescribed by pediatricians, rhinologists, and allergologists. Although they act directly on the nasal mucosa, dose-related systemic adverse effects associated to long-term treatments, such as suppression of adrenocortical function, growth, and bone metabolism, ${ }^{40-42}$ are considered a questionable issue with the use of CS in children.

Specialists should always recommend the minimal dose necessary to control the symptoms; systemic side effects are actually uncommon.

\section{HMGB1: New Frontiers for Therapy}

All the studies reported in this review suggest that HMGB1 inhibition might be an effective and innovative therapeutic target for patients with allergic rhinitis, chronic upper airways, and nasal mucosa inflammatory diseases.

HMGB1 inhibition is obtained by three main strategies:

1) Blocking HMGB1 release by necrotic cells and activated immune cells. This is a disadvantageous mechanism because it suppresses the protein physiological homeostatic function in all cells with serious side effects.

2) Blocking RAGE, TLR2, TLR9 receptors with antagonist drugs. This mechanism is risky because HMGB1 receptors also mediate other immune effects, such as the antibacterial activity.

3) Inactivating HMGB1 after its release. This is currently the most effective and safest strategy.

Musumeci et al described various approaches recently proposed in the literature to inhibit HMGB1 and the related inflammatory process, especially focusing on the block of RAGE-HMGB1 signaling. ${ }^{31}$

Among the small-molecule inhibitors of HMGB1 is one called glycyrrhizin, a glycoside alkaloid found in large quantities in Glicyrrhiza glabra roots, the plant from which licorice is extracted. Glycyrrhizin is composed of a molecule of glycyrrhetic acid (GA) (the active component of the molecule) and two molecules of glucuronic acid. ${ }^{43}$

The interest of the scientific community in alternative therapies, among which is phytotherapy, has grown rapidly in the last decades for several reasons: to find better therapeutic options or solutions where these are lacking, to discover new and safer therapies free from Adverse Events $(\mathrm{AE})$, to search for alternative solutions where traditional Medicine has not shown satisfying results or even damaging ones in the long term. In this context, however, modern phytotherapy should be differentiated from herbalism (i.e., the study of the use of row extracts from natural origin as medicine) and should rather be considered a scientifically 
and critically conducted study on the effect and clinical use of herbal medicine in which plant-derived compound follow standard quality and safety principles.

Glycyrrhetic acid, its salts and esters, and Glycyrrhizic acid, and its salts and esters, should not be considered plant extracts, powders, or juices, but rather specific chemical species that are isolated from the licorice plant. These compounds have shown to possess the above-mentioned characteristics both in pre-clinical and clinical studies. ${ }^{44,45}$

The GA inhibits the HMGB1 chemotactic and mitogenic function binding to the hydrophobic residues that border the pockets in Box A and B, without significantly distorting their secondary structure and, hence, without impeding the ability of DNA binding. ${ }^{46,47}$

Humans seem to tolerate the GA well and there are no adverse effects when it is administered intravenously at a dose of $240 \mathrm{mg}$ three times a week for 4 weeks.

Several studies have shown an absence of cytotoxicity, even at high concentration and good pharmacological tolerance of glycyrrhizin by rats and humans. ${ }^{48}$

With this background, recent studies have evaluated the potential therapeutic effects of GA in ENT diseases, particularly allergic rhinitis in children.

A pilot study ${ }^{21}$ showed that the associations of GA with osmotically acting drugs increases beneficial effects determining potent and fast antiedema actions, while glycyrrhizin acts with anti-inflammatory properties as well.

This single-center prospective study included 20 consecutively enrolled children of both genders with allergic rhinitis. The enrolled children received one puff of a medical device with antiedematous and anti-inflammatory characteristics thanks to its components (such as eucalyptol, glycyrrhizin, and mannitol) at high concentrations as osmotically active agents into each nostril twice a day over the course of four weeks. We subjectively assessed the severity of major symptoms associated with AR, such as nasal congestion, rhinorrhea, sneezing, and nasal itching, and classified them according to a 0 to 10 visual analogue scale (VAS). We compared differences in subjective severity measures before and after treatment using Paired-Sample Wilcoxon Signed Rank Test: nasal congestion, rhinorrhea, and sneezing significantly improved after treatment $(p<0.001)$. The use of this medical device has been proven to be an efficient solution in the treatment of nasal congestion and helps to clear the nose, especially before eating or sleeping.

Two studies have evaluated the short-term ( 7 days) and long-term (30 days) efficacy and safety of the same medical device for treating nasal congestion in allergic patients. ${ }^{18,19}$ They assessed both patients' perception of nasal symptoms and objective testing of nasal obstruction. Results demonstrated a significant improvement in all major symptoms of allergic rhinitis, including rhinorrhea, sneezing, and nasal obstruction after treatment in both groups, not showing a significant difference when comparing percentage reaction. Together with the subjective self-assessment of nasal obstruction by VAS, physical examination of treated patients also showed a significant improvement in turbinate hypertrophy and secretory activity. Patients reported no adverse effects over the treatment period and compliance was generally high.

Finally, two studies ${ }^{23,24}$ have evaluated the efficacy of the GA versus intranasal corticosteroids therapy in the management of allergic rhinitis symptoms in a pediatric population.

In the single-center, two-parallel group, randomized study by Mansi et $\mathrm{al}^{24}$ the HMGB1 levels were high in the nasal mucus of children with AR and both intranasal corticosteroid and GA were able to diminish them. They evaluated 35 children with allergic rhinitis monosensitized to Parietaria. They randomly assigned the children to receive GA, nasal corticosteroids, or placebo as nasal spray, for seven days. Comparing the HMGB1 levels at baseline and after 7 days of treatment, there were significant differences of HMGB1 expression: at baseline, HMGB1 levels in nasal mucus were higher in children with AR than in the control group $(96.9 \pm 19.3 \mathrm{ng} / \mathrm{ml}$ vs $9.27 \pm 4.01 \mathrm{ng} / \mathrm{ml} ; p<0.001)$. After one week of treatment, HMGB1 levels in nasal mucus were significantly diminished $(p<0.001)$ in children treated with GL or CS $(23.5 \pm 6.3 \mathrm{ng} / \mathrm{ml}$ and $28.14 \pm 7.2 \mathrm{ng} / \mathrm{ml}$, respectively) compared with placebo $(72.6 \pm 12.7 \mathrm{ng} / \mathrm{ml})$. They observed no significant difference between the two treatment groups (CS versus GL). GA appears to be efficacious in treating nasal congestion and other major symptoms (sneezing, rhinorrhea, nasal obstruction) in children with AR over a 30-day period, showing results comparable to intranasal corticosteroids therapy but with a better safety profile. Nasal itching improvement was significant only in the group receiving corticosteroids.

Cavone et $\mathrm{al}^{33}$ found increased HMGB1 level in nasal fluids of patients with different forms of rhinitis (AR, NARES-NonAllergic Rhinitis with Eosinophilia Syndrome, CRSwNP). In the same study, they found that a formulation containing the HMGB1-binding compound glycyrrhizin (GLT) reduces the HMGB1 content in nasal fluid to an extent similar to that of the nasal budesonide treatment. In addition, through an experimental model, they better evidenced the therapeutic potential of HMGB1-inactivating strategies in the treatment of inflammatory disorders of the nasal mucosa: in fact, they found that, among the cultured human leukocyte populations, eosinophils release higher amounts of HMGB1. As eosinophils are the only leukocyte subtype that needs HMGB1 for survival, the reduced HMGB1 level in nasal fluids of a patient affected with rhinitis can be attributed to the capacity of GLT to selectively kill eosinophils, which are a major source of extracellular HMGB1.

One of the last novelties in the scientific literature about HMGB1 and AR is that ethyl pyruvate (EP) has been proven to be an effective anti-inflammatory agent for numerous airway diseases. EP can inhibit the secretion of HMGB1: Chen et $\mathrm{al}^{49}$ have demonstrated, in an experimental model, that EP significantly inhibits several features of the allergic inflammatory response, including airway eosinophilia, Th2-cytokines expression, total IgE, goblet cell hyperplasia, and nasal symptoms. Many different mechanisms contribute to the anti-inflammatory effects of EP, and one of them is the inhibition of HMGB1 release. The expression and translocation of HMGB1 were significantly inhibited by the treatment 
with EP in a dose-dependent manner. However, no clinical studies have examined the effect of EP on AR. Thus, the exact signal pathway through which EP inhibits HMGB1 expression has yet to be established.

\section{Discussion}

Our review shows that HMGB1 should be considered and is a suitable marker of inflammation in upper airways diseases, as it happens in several systemic and autoimmune diseases.

As a consequence, HMGB1 inhibition may be an innovative therapeutic target for patients with chronic upper airway inflammatory diseases, with nasal obstruction as a major symptom. Among inhibitors of HMGB1, GA has been proven to be effective in adults and children: in contrast to corticosteroids or antihistamines, it appears to be well tolerated and there are no side effects in humans.

Let us not forget the socio-economic impact of rhinitis with respect to quality of life and its direct and indirect costs. In this view, via a Monte Carlo simulation study, data on disease prevalence, drug prescription, and cost of both the specific therapeutic approach and the adverse events treatment were combined to provide an estimate of the overall cost of the traditional pharmacotherapy, as compared with the medical device based on GA and osmotic agents. ${ }^{20}$ This simulation study on the economic advantages of adopting the medical device as a standard therapeutic agent for targeting AR and non-allergic rhinitis (NAR) has shown that the overall economic impact of the two diseases could be reduced by $\sim 3.5 \%$ yearly.

However, the cost-impact analysis was although performed using the most updated stochastic techniques, biases could have been introduced in the analysis due to neglecting complex interactions among treatments and patient characteristics, which have been ignored in the study due to lack of information.

\section{Final Comments}

HMGB1 has a role in the pathogenesis of chronic nasal mucosa inflammatory diseases such as allergic rhinitis, chronic rhinosinusitis, and nasal polyposis. HMGB1 inhibition might be an effective and innovative therapeutic target for patients with allergic rhinitis, chronic upper airways, and nasal mucosa inflammatory diseases. GA inhibits HMGB1 chemotactic and mitogenic function by a scavenger mechanism on extracellular HMGB1 accumulation stimulated by lipopolysaccharides in vitro. Treatment of allergic rhinitis with GA is not associated with local or systemic side-effects in children and adults.

It seems important to suggest that clinical and experimental research on these topics should be continued with the aim of reducing issues arising from diseases, which are not only pertinent to otorhinolaryngology.

It is worth noting that, in spite of these encouraging and promising results, GA has not yet been included as the treatment option for patients with chronic rhinitis/rhinosinusitis in any one of the current guidelines and position papers such as ARIA guideline, EPOS 2012, International Consensus of Allergy \& Rhinology 2016.
Since their introduction, the topically administered glucocorticosteroids have been the first-line treatment for chronic rhinitis and rhinosinusitis. Their clinical efficacy depends in part on their ability to reduce airway eosinophils infiltration by preventing their increased viability and activation; in other words, both glucocorticosteroids and GA have eosinophils survival and activation as therapeutic targets. Nevertheless, intranasal corticosteroids are not completely devoid of local and systemic effects. Epistaxis, dry nose, nasal burning, and irritation are minor local events, usually well-tolerated by the patients; very rarely septal perforation has been reported but it is not clear whether this event should be attributed to the mucosa microtraumatisms generated by the attitude of children "to explore" their nose with their fingers or to the drug itself. Thus, care has to be taken, especially in children, when long-term treatments are prescribed. Potential systemic AE are effects on growth, ocular effects, effects on bone, and on the hypothalamic-pituitaryadrenal axis. Because the dose absorbed after topical delivery is small, these are not a major consideration, and extensive studies have not identified significant systemic effects. Nevertheless, in elderly patients, because of physiological changes in renal function and when certain comorbidities are present (diabetes mellitus, hypertension, arrhythmia, asthma, COPD) some special considerations are necessary, especially for prolonged treatments. Thus, in special categories of patients (children and elderly, subjects already taking many medications), GA can represent a good alternative to standard treatment options.

\section{Conflict of Interest and Financial Disclosure}

The authors declare that there is no conflict of interest and that no financial support or interest is vested in this study.

\section{References}

1 Turner PJ, Kemp AS. Allergic rhinitis in children. J Paediatr Child Health 2012;48(4):302-310

2 Kemp AS. Allergic rhinitis. Paediatr Respir Rev 2009;10(2):63-68

3 Konstantinopoulou S, Sideris GA, DelRosso LM. The Role of Co-Morbidities. Curr Probl Pediatr Adolesc Health Care 2016; 46(1):7-10

4 Gentile D, Bartholow A, Valovirta E, Scadding G, Skoner D. Current and future directions in pediatric allergic rhinitis. J Allergy Clin Immunol Pract 2013;1(3):214-226, quiz 227

5 Brozek JL, Bousquet J, Baena-Cagnani CE, et al; Global Allergy and Asthma European Network; Grading of Recommendations Assessment, Development and Evaluation Working Group. Allergic Rhinitis and its Impact on Asthma (ARIA) guidelines: 2010 revision. J Allergy Clin Immunol 2010;126(3):466-476

6 Lunn M, Craig T. Rhinitis and sleep. Sleep Med Rev 2011;15(5): 293-299

7 Craig TJ, Sherkat A, Safaee S. Congestion and sleep impairment in allergic rhinitis. Curr Allergy Asthma Rep 2010;10(2):113-121

8 Sardana N, Craig TJ. Congestion and sleep impairment in allergic rhinitis. Asian Pac J Allergy Immunol 2011;29(4):297-306

9 Canonica GW, Compalati E. Minimal persistent inflammation in allergic rhinitis: implications for current treatment strategies. Clin Exp Immunol 2009;158(3):260-271

10 Lotze MT, Tracey KJ. High-mobility group box 1 protein (HMGB1): nuclear weapon in the immune arsenal. Nat Rev Immunol 2005; 5(4):331-342 
11 Wittemann B, Neuer G, Michels H, Truckenbrodt H, Bautz FA. Autoantibodies to nonhistone chromosomal proteins HMG-1 and HMG-2 in sera of patients with juvenile rheumatoid arthritis. Arthritis Rheum 1990;33(9):1378-1383

12 Popovic K, Ek M, Espinosa $A$, et al. Increased expression of the novel proinflammatory cytokine high mobility group box chromosomal protein 1 in skin lesions of patients with lupus erythematosus. Arthritis Rheum 2005;52(11):3639-3645

13 Vroling AB, Fokkens WJ, van Drunen CM. How epithelial cells detect danger: aiding the immune response. Allergy 2008;63(9): 1110-1123

14 Park JS, Svetkauskaite D, He Q, et al. Involvement of toll-like receptors 2 and 4 in cellular activation by high mobility group box 1 protein. J Biol Chem 2004;279(9):7370-7377

15 Passali D, Kern E, Lei Chen R, Bellussi L. High mobility group box 1 (HMGB 1): a new protein in the pathogenesis of ENT inflammatory and infectious diseases. Acta Otorhinolaryngol Ital 2012;32(1):46-47

16 Bellussi LM, Chen L, Chen D, Passali FM, Passali D. The role of High Mobility Group Box 1 chromosomal protein in the pathogenesis of chronic sinusitis and nasal polyposis. Acta Otorhinolaryngol Ital 2012;32(6):386-392

17 Salpietro C, Cuppari C, Grasso L, et al. Nasal high-mobility group box-1 protein in children with allergic rhinitis. Int Arch Allergy Immunol 2013;161(2):116-121

18 Damiani V, Camaioni A, Viti C, et al. Short-term Efficacy of Narivent ${ }^{\circledR}$ in the Treatment of Nasal Congestion. Open Med Dev J 2012;4:66-72

19 Damiani V, Camaioni A, Viti C, Scirè AS, Morpurgo G, Gregori D. Long-term Efficacy of Narivent ${ }^{\circledR}$ in the Treatment of Nasal Congestion. Open Med Dev J 2012;4:73-79

20 Damiani V, Vicheva D, Camaioni A, et al. Economic Impact of Treatments for Controlling Symptoms Associated with Rhinitis: an Evaluation of Narivent ${ }^{\circledR}$ vs Standard Therapy. The Open Med Dev J 2012;4:61-65

21 Mansi N, D’Agostino G, Scirè AS, Morpurgo G, Gregori D, Damiani V. A before-after assessment of the efficacy of Narivent ${ }^{\circledR}$ in the treatment of symptoms associated with allergic rhinitis in a pediatric population. Open Med Dev J 2012;4:80-86

22 Damiani V, Camaioni A, Viti C, Scirè AS, Morpurgo G, Gregori D. A single-centre, before-after study of the short- and long-term efficacy of Narivent $\left({ }^{\circledR}\right)$ in the treatment of nasal congestion. J Int Med Res 2012;40(5):1931-1941

23 Cuppari C, Salpietro A, Grasso L, et al. HMGB1 and allergic rhinitis in children: preliminary results after corticosteroids or glycyrrhetic acid intranasal treatment. The Child 2012;1; (2):1-2

24 Mansi N, D'Agostino G, Scirè AS, et al. Allergic Rhinitis in Children: A Randomized Clinical Trial Targeted at Symptoms. Indian J Otolaryngol Head Neck Surg 2014;66(4):386-393

25 Hong SM, Cho JS, Um JY, et al. Increased expression of highmobility group protein B1 in chronic rhinosinusitis. Am J Rhinol Allergy 2013;27(4):278-282

26 Bellussi LM, Iosif C, Sarafoleanu C, et al. Are HMGB1 protein expression and secretion markers of upper airways inflammatory diseases? J Biol Regul Homeost Agents 2013;27(3):791-804

27 Chen D, Bellussi LM, Passali D, Chen L. LPS may enhance expression and release of HMGB1 in human nasal epithelial cells in vitro. Acta Otorhinolaryngol Ital 2013;33(6):398-404

28 Ullah MA, Loh Z, Gan WJ, et al. Receptor for advanced glycation end products and its ligand high-mobility group box- 1 mediate allergic airway sensitization and airway inflammation. J Allergy Clin Immunol 2014;134(2):440-450

29 Chen D, Mao M, Bellussi LM, Passali D, Chen L. Increase of high mobility group box chromosomal protein 1 in eosinophilic chronic rhinosinusitis with nasal polyps. Int Forum Allergy Rhinol 2014; 4(6):453-462

30 Paris G, Pozharskaya T, Asempa T, Lane AP. Damage-associated molecular patterns stimulate interleukin-33 expression in nasal polyp epithelial cells. Int Forum Allergy Rhinol 2014;4(1):15-21
31 Musumeci D, Roviello GN, Montesarchio D. An overview on HMGB1 inhibitors as potential therapeutic agents in HMGB1related pathologies. Pharmacol Ther 2014;141(3):347-357

32 Min HJ, Kim SJ, Kim TH, Chung HJ, Yoon JH, Kim CH. Level of secreted HMGB1 correlates with severity of inflammation in chronic rhinosinusitis. Laryngoscope 2015;125(7):E225-E230

33 Cavone L, Cuppari C, Manti S, et al. Increase in the level of proinflammatory cytokine HMGB1 in nasal fluids of patients with rhinitis and its sequestration by glycyrrhizin induces eosinophils cell death. Clin Exp Otorhinolaryngol 2015;8(2): 123-128

34 Dzaman K, Szczepanski MJ, Molinska-Glura M, Krzeski A, Zagor M. Expression of the receptor for advanced glycation end products, a target for high mobility group box 1 protein, and its role in chronic recalcitrant rhinosinusitis with nasal polyps. Arch Immunol Ther Exp (Warsz) 2015;63(3):223-230

35 Dzaman K, Zagor M, Molinska-Glura M, Krzeski A. High motility group box 1 (HMGB1) protein and its receptor for advanced glycation end products (RAGE) expression in chronic rhinosinusitis without nasal polyps. Folia Histochem Cytobiol 2015;53(1):70-78

36 Bousquet J, Khaltaev N, Cruz AA, et al; World Health Organization; GA(2)LEN; AllerGen. Allergic Rhinitis and its Impact on Asthma (ARIA) 2008 update (in collaboration with the World Health Organization, GA(2)LEN and AllerGen). Allergy 2008;63 (Suppl 86):8-160

37 Passàli D, Salerni L, Passàli GC, Passàli FM, Bellussi L. Nasal decongestants in the treatment of chronic nasal obstruction: efficacy and safety of use. Expert Opin Drug Saf 2006;5(6):783-790

38 Baena-Cagnani CE. Safety and tolerability of treatments for allergic rhinitis in children. Drug Saf 2004;27(12):883-898

39 Storms W. Update on montelukast and its role in the treatment of asthma, allergic rhinitis and exercise-induced bronchoconstriction. Expert Opin Pharmacother 2007;8(13):2173-2187

40 Howland WC III. Fluticasone propionate: topical or systemic effects? Clin Exp Allergy 1996;26(Suppl 3):18-22

41 Howland WC III, Hampel FC Jr, Martin BG, Ratner PH, van Bavel JH, Field EA. The efficacy of fluticasone propionate aqueous nasal spray for allergic rhinitis and its relationship to topical effects. Clin Ther 1996;18(6):1106-1117

42 Mener DJ, Shargorodsky J, Varadhan R, Lin SY. Topical intranasal corticosteroids and growth velocity in children: a meta-analysis. Int Forum Allergy Rhinol 2015;5(2):95-103

43 Ploeger B, Mensinga T, Sips A, Seinen W, Meulenbelt J, Dejongh J. The pharmacokinetics of glycyrrhizic acid evaluated by physiologically based pharmacokinetic modeling. Drug Metab Rev 2001; 33(2):125-147

44 Saeedi M, Morteza-Semnani K, Ghoreishi MR. The treatment of atopic dermatitis with licorice gel. J Dermatolog Treat 2003;14(3):153-157

45 Cosmetic Ingredient Review Expert Panel. Final report on the safety assessment of Glycyrrhetinic Acid, Potassium Glycyrrhetinate, Disodium Succinoyl Glycyrrhetinate, Glyceryl Glycyrrhetinate, Glycyrrhetinyl Stearate, Stearyl Glycyrrhetinate, Glycyrrhizic Acid, Ammonium Glycyrrhizate, Dipotassium Glycyrrhizate, Disodium Glycyrrhizate, Trisodium Glycyrrhizate, Methyl Glycyrrhizate, and Potassium Glycyrrhizinate. Int J Toxicol 2007;26 (2, Suppl 2)79-112

46 Yang H, Wang H, Czura CJ, Tracey KJ. HMGB1 as a cytokine and therapeutic target. J Endotoxin Res 2002;8(6):469-472

47 Mollica L, De Marchis F, Spitaleri A, et al. Glycyrrhizin binds to high-mobility group box 1 protein and inhibits its cytokine activities. Chem Biol 2007;14(4):431-441

48 van Rossum TG, Vulto AG, Hop WC, Brouwer JT, Niesters HG, Schalm SW. Intravenous glycyrrhizin for the treatment of chronic hepatitis C: a double-blind, randomized, placebo-controlled phase I/II trial. J Gastroenterol Hepatol 1999;14(11):1093-1099

49 Chen S, Wang Y, Gong G, Chen J, Niu Y, Kong W. Ethyl pyruvate attenuates murine allergic rhinitis partly by decreasing high mobility group box 1 release. Exp Biol Med (Maywood) 2015; 240(11):1490-1499 